\title{
Quando canto é reza: lazer, morte e greve na formação da classe trabalhadora na Freguesia da Gávea (1896-1917)
}

\section{Mariana Barbosa Carvalho da Costa*}

Resumo: Os principais jornais da capital federal noticiaram, em janeiro de 1917, que os operários da Fábrica Carioca, situada na Freguesia da Gávea, decidiram paralisar os trabalhos. Era somente mais uma das paralisações operárias, aparentemente, sob a orientação anarquista que teria desencadeado a deflagração de diversas greves na cidade. Uma análise mais atenta sobre as experiências dos trabalhadores do bairro nos anos anteriores indica, contudo, a necessidade de entender a lógica particular de mobilização que se expressava durante a greve. Sendo assim, este trabalho tem por objetivo buscar compreender tais motivações a partir das formas anteriores de organização entre aqueles operários, em especial nos muitos clubes dançantes formados na região. Por meio de publicações na imprensa sobre esses clubes e dos pedidos de licença por eles apresentados à polícia, torna-se possível buscar uma compreensão mais ampla sobre os prováveis sentidos daquele movimento para muitos de seus participantes.

Palavras-chave: Clubes dançantes; Gávea; Costumes.

\begin{abstract}
In January 1917 the Federal Capital's major newspapers reported that the workers of the factory Carioca, located in the neighborhood of Gávea, decided to strike. Apparently, it was just another manifestation of workers who, under the guidance anarchist, would have caused the eruption of several strikes in the city. The specific motivations of the manifestation indicated the needs to understand the specific logic of mobilization of the movement. Considering previous forms of organization formed by groups of workers associated with dance clubs in the neighborhood, we can seek a path of the investigation. Through the demand of the license and notices published by the press about these clubs, it is possible to investigate a meaning assigned by them to such an organization.
\end{abstract}

Keywords: Dancing clubs; Gávea; Customs.

No dia 6 de janeiro de 1917, os operários da Fábrica de Tecidos Carioca, situada na Freguesia da Gávea, declararam-se em greve. Segundo a Gazeta de Notícias, o problema que deflagrou o movimento havia se iniciado quando alguns operários pediram dispensa para acompanhar o enterro da filha de um companheiro. A licença não fora concedida, pois o mestre geral julgou ser inconveniente dispensar pessoal devido à falta de alguns operários naquele dia. ${ }^{1}$ Frente à insatisfação dos trabalhadores, o Jornal do Brasil afirma que três operários foram chamados ao escritório, acusados pela diretoria de incitar o descontentamento dos demais. Esta comunicava ainda a proibição da saída de operários durante o horário de trabalho sob qualquer pretexto:

\footnotetext{
* Mestranda no Programa de História Social da Cultura da PUC-Rio- bolsista Capes.

1 “A greve na fábrica Carioca”. Gazeta de Notícias. 8 jan. 1917.
} 
Isso acabou por irritar profundamente todo o pessoal da fábrica, cerca de três mil operários, que entraram a murmurar, a protestar.

[...] Os mais exaltados abandonaram o trabalho, outros foram imitando e dentro em pouco operários, operárias e menores abandonavam seus afazeres em um movimento coletivo de protesto e de solidariedade com os companheiros, saindo todos para os pátios da fábrica. ${ }^{2}$

Em meio à confusão que se instaurou, outro grupo igualmente numeroso de operários encontrou Dixson Myller, o mestre geral da sessão de teares, que acabou por ser agredido pelo grupo. A diretoria resolveu então suspender os três operários e demitir outros cinco, responsabilizados pela agressão. Daquele momento em diante, todos os operários das duas fábricas da Companhia de Fiação e Tecidos Carioca paralisariam suas atividades, reivindicando tanto a revogação das medidas que atingiam diretamente seus companheiros suspensos e demitidos quanto a demissão do mestre geral. ${ }^{3}$

Ao tentar explicar o que havia desencadeado essa parede, o jornal $O$ Paiz destacou a relação que se estabelecia entre os operários do estabelecimento fabril e o mestre geral da sessão de tinturaria, Eduardo Rester:

Grande animosidade havia, de há muito, na fábrica de tecidos Carioca, entre os operários de todos dois sexos, e o mestre geral Eduardo Reter, que não cessava de Ihes fazer picardias, impondo-Ihes exigências absurdas, intrigando-os com a diretoria da fábrica, inventando diariamente ordens novas, severas e inexequíveis, só para maior desprestigiados operários, homens e mulheres ali ocupados. ${ }^{4}$

O fragmento referia-se à medida tomada pelo mestre geral de trancar o banheiro utilizado pelos operários, sob a justificativa de que aproveitavam para não trabalhar, acabando por afetar principalmente as mulheres que se envergonhavam de pedir para usálo, o que, do ponto de vista do mestre geral, poderia se converter numa estratégia de ditar o seu ritmo de trabalho. O Jornal do Brasil fazia o mesmo ao noticiar o ocorrido e, referindo-se ao caso da utilização do sanitário, acrescentava que o tempo demorado para satisfazer essa necessidade era contabilizado e descontado do salário daqueles operários. ${ }^{5} \mathrm{O}$ jornal operário $A$ Razão não diferia ao enfatizar que a diretoria impediria o ocorrido: "Se há muito já tivesse substituído o mestre geral Eduardo Prestes, cuja a moral, conduta e atos menos dignos o tem tornado incompatível com os operários, mas, a diretoria nunca quis atender as justas reclamações desses obreiros do trabalho..."

Os articulistas da imprensa construíam, assim, uma percepção das causas que levaram à paralisação dos operários que desencadeou aquela greve, como sugeria o Jornal do Brasil ao comentar que "pacientemente, os operários iam suportando tudo, mas uma cólera sendo lavrada entre todos e um movimento de revolta estava prestes a explodir,

\footnotetext{
2 “Na polícia e nas ruas”. Jornal do Brasil. 6 jan. 1917.

3 "A greve na Carioca". A Razão. 6 jan. 1917.

4 "A greve na fábrica de tecidos Carioca”. O Paiz. 6 jan. 1917.

5 “Movimento paredista". Jornal do Brasil. 6 jan. 1917.

6 “A greve na Carioca”. A Razão. 6 jan. 1917.
} 
aguardando a primeira oportunidade". ${ }^{7}$ A greve seria assim, nessa leitura, uma consequência direta dessas práticas de exploração, que causaram uma revolta capaz de dar forma ao movimento.

Se a exploração era evidente e reconhecida pela grande imprensa, a possibilidade de reação dos operários locais a ela aparecia, para alguns contemporâneos, como uma novidade difícil de explicar. Ao destacar a força do movimento grevista, um articulista do jornal operário de orientação anarquista $A$ Razão mostrava-se surpreso com o fato de que os operários estivessem até aquele momento firmes em greve durante nove dias, "e tudo isso conseguido sem um entendimento prévio, sem uma associação de classe, sem uma direção preestabelecida" ${ }^{8}$ Seu testemunho a respeito da espontaneidade do movimento, cuja lógica e força os próprios militantes anarquistas pareciam não compreender, sugere assim a necessidade de olharmos para ele de forma mais detida, de modo a tentar entender que fenômenos poderiam explicar a organização daquele movimento.

Chama-nos a atenção, em primeiro lugar, o momento em que se deu a parede na Fábrica Carioca: o início do emblemático ano de 1917. Em julho desse mesmo ano, viria a ser deflagrada uma greve geral de grandes proporções na cidade. Os jornais de maior circulação noticiavam uma paralisação patrocinada por diversas categorias de trabalhadores. Dentre eles, destacavam-se justamente os trabalhadores da indústria têxtil, como sugere uma nota do jornal O Paiz: "Já se declararam em greve, exigindo $30 \%$ de aumento de salário, os tecelões das fábricas de tecidos Andaray, Confiança, Bonfim, Toreno e Cruzeiro, além dos da fábrica de tecidos Carioca, que se acham já em greve há vários dias." ${ }^{9}$ Vemos assim como o ano que se abrira com uma paralisação restrita aos operários da Fábrica Carioca ficaria marcado, ao seu fim, por um movimento de dimensões muito amplas, no qual esses operários participaram ativamente. ${ }^{10}$

A greve geral desencadeada em julho de 1917 foi objeto de grande atenção por parte da historiografia. Para alguns autores, essa seria uma decorrência direta da força da doutrina anarquista entre o movimento operário carioca. É o que explica Carlos Addor, ao enfatizar a configuração da força do anarquismo na Primeira República. Para o autor, a corrente anarquista se disseminou durante aquele período, principalmente porque o estado, simultaneamente liberal e oligárquico, não intervinha de forma normativa na sociedade. Além disso, não reconhecia o movimento operário como interlocutor legítimo, e ainda o reprimia constantemente. Recusando-se, portanto, a travar a luta no âmbito políticoinstitucional, como atuavam os socialistas, a corrente anarquista constituía um apelo maior

\footnotetext{
7 “Movimento paredista”. Jornal do Brasil. 6 jan. 1917.

8 "A greve na Carioca”. A Razão. 13 jan. 1917.

9 "A greve". O Paiz. 25 jul. 1917.

${ }^{10}$ Paralisações amplas como aquelas não constituíam exatamente uma novidade entre os trabalhadores da capital federal. Ainda em 1903, Marcela Goldmacher, ao argumentar que a greve de agosto de 1903, tida pelos contemporâneos como greve geral, reuniu diversas categorias de trabalhadores, especialmente os trabalhadores do ramo de tecelagem, representados por diferentes associações com funções sindicais e/ou mutualistas. GOLDMACHER, Marcela. “As associações operárias e a 'Greve Geral' de 1903”. In: GOLDMACHER, Marcela; MATTOS, Marcelo Badaró; TERRA, Paulo Cruz (org.). Faces do Trabalho: escravizados e livres. Rio de Janeiro: EDUFF, 2010.
} 
entre os trabalhadores, fazendo da ação direta o meio privilegiado de atuação. Desse modo, na conjuntura de ascensão do movimento operário e êxito da orientação anarquista, as greves tiveram um papel fundamental, destacando-se, nesse sentido, a "greve generalizada de julho de 1917" no Distrito Federal. As motivações principais para essa paralisação, argumentou Addor, advêm de questões relacionadas à carestia da vida, o protagonismo da Federação Operária do Rio de Janeiro, criada em 1906, tido como ano emblemático da ascensão do anarquismo no cenário republicano, e solidariedade para com os companheiros paulistas, que também se encontravam em greve. Sendo assim, o ano de 1917 é, para Addor, um momento privilegiado na formação da classe, em processo que teria consagrado a força do anarquismo entre os trabalhadores cariocas. ${ }^{11}$

Em sentido diverso, Marcelo Badaró lançou sobre a questão outro tipo de olhar. Sem colocar no anarquismo seu foco, ele buscou nas formas anteriores de organização dos trabalhadores cariocas as pistas para entender a insurgência dos grandes movimentos de articulação de trabalhadores no início do século XX. Nesse sentido, o historiador reconhece que existia nas associações de auxílio mútuo, formadas por trabalhadores livres e assalariados, desde meados do século XIX, um caráter classista, que se expressava na solidariedade para com seus companheiros e na defesa de ofício, constituindo o processo de formação da classe. Contudo, as raízes de tal forma de associação eram, para ele, ainda mais profundas - podendo ser buscadas mesmo nas irmandades religiosas - organizações de corporações portuguesas que logo foram apropriadas por negros, que constituíram irmandades próprias nas quais mantinham o objetivo de auxílio mútuo. Badaró argumenta que ocorreu certa convivência de experiências organizativas entre tais associações mutualistas e as associações com funções de defesa de interesses de classe, ambas criadas na segunda metade do século XIX. As ações de caráter mutualista presentes nessas associações, formadas no final do século XIX, passavam a compor as práticas das associações de classe durante o século XX. No entanto, o mutualismo não era mais o centro do associativismo em relação à representação dos interesses dos trabalhadores, nesse momento representados por aquelas associações de classe, como os próprios sindicatos. ${ }^{12}$

Um esforço similar de transcender uma explicação sobre as formas de mobilização do operariado na Primeira República baseada somente na força do anarquista é apresentado no artigo "Cultura Associativa no Rio de Janeiro da Primeira República", de Claudio Batalha. Para o autor, desde o final do século XIX, a cultura associativa entendida como "o conjunto de propostas e práticas culturais das organizações operárias" constituía-se em práticas ritualizadas que eram efetivadas por sociedades mutualistas, políticas ou culturais. Dentre essas práticas, destacam-se as celebrações do primeiro de maio. Nas duas primeiras décadas do século $X X$, estabelecia-se a cultura militante, influenciada pela cultura associativa, mas também distinta dela, na medida em que assumia aspectos particulares a cada corrente ideológica, assim como traços comuns a elas. Ainda que surgida posteriormente, a cultura militante conformaria, em certa medida, a cultura associativa. Com a criação e consolidação

\footnotetext{
${ }^{11}$ ADDOR, Carlos. História do Anarquismo no Brasil. Rio de Janeiro: Achiame, 2009.

${ }^{12}$ MATTOS, Marcelo Badaró. Escravizados e Livres. Rio de Janeiro: Bom texto, 2008.
} 
das instituições do movimento operário, a emblemática data do primeiro de maio passou a ser celebrada com maior constância e com dimensões mais amplas. Nesse momento, adquiria contornos mais específicos e ritualizados, com sentidos simbólicos próprios àquela experiência. Ganhava, assim, maior importância no movimento operário até a década seguinte. Durante a década de 1920, começariam a surgir indícios de que essa cultura militante transformava-se em cultura de classe, caracterizando o processo de formação da classe trabalhadora. A cultura associativa mudava seu perfil com a incorporação na política sindical das associações de classe de certas práticas, atingindo um maior número de trabalhadores. Caso, por exemplo, do futebol, que passava a fazer parte das práticas realizadas nos festivais operários. No entanto, para o autor, ao não se concretizarem espaços autônomos de classe, houve a inviabilização da formação da cultura de classe naquele momento. ${ }^{13}$

Carlos Addor atribuiu a mobilização dos trabalhadores durante a Primeira República à difusão da ideologia anarquista no movimento operário, caracterizando, assim, o processo de formação da classe trabalhadora no Brasil. Badaró e Batalha, por outro lado, ao articularem práticas associativas distintas e formas de mobilização sindical, em suas especificidades de análise, contribuem para formular o problema de identificar a construção de solidariedade e identidade dos trabalhadores a partir de suas próprias formas de organização e luta. Contudo, é somente a partir das associações e práticas realizadas no próprio movimento operário que os autores buscaram entender como tais laços de solidariedade e identidade se gestaram. A proposta deste trabalho consiste, no entanto, em identificar a articulação dos laços de solidariedade entre os operários na paralisação grevista dos operários da Fábrica Carioca em janeiro de 1917, conduzindo a investigação em direção a outra experiência associativa anterior desses sujeitos, que consiste nos clubes dançantes formados pelos trabalhadores da região. Por meio desse caminho, podemos tentar compreender outras dimensões do processo de construção de identidade de classe entre os trabalhadores cariocas do período, cujos efeitos mais visíveis seriam vistos ao longo da greve de julho de 1917.

\section{UM BAIRRO EM FESTA}

Cerca de vinte anos antes da greve que, em janeiro de 1917, paralisaria as atividades da Fábrica Carioca, os moradores da região já apareciam nas páginas da grande imprensa carioca por motivos bem diversos. "Já não tem conta o número de sociedades, clubes e grupos que ensaiam seus voos para as próximas festas carnavalescas, que prometem ser simplesmente esplêndidas!"14, anunciava o Jornal do Brasil em janeiro de 1898, ao tratar dos festejos carnavalescos que se aproximavam. Dentre eles, mereceu destaque o Clube Carnavalesco Chuveiro de Ouro, formado no que era então conhecido

\footnotetext{
${ }^{13}$ BATALHA, Claudio. "Cultura Associativa no Rio de Janeiro da Primeira República”. In: Culturas de Classe: identidade e diversidade na formação do operariado. Campinas: Editora da UNICAMP, 2004.

14 "Carnaval”. Jornal do Brasil. 7 jan. 1898.
} 
como o bairro da Gávea (que compreendia parte do atual Jardim Botânico e São Conrado). Segundo a nota, o clube desfilou durante a tarde e a noite, "com seus três ricos estandartes e numeroso séquito, que passeou ontem pelas principais ruas da cidade ao som de um sem número de pandeiros". ${ }^{15}$ Fundado em 2 de fevereiro de 1896, ele tinha sua sede na rua Lopes Quintas, no atual Jardim Botânico. Tratava-se, aparentemente, do primeiro clube voltado para fins propriamente carnavalescos da região, mas certamente não seria o último. ${ }^{16}$ De fato, o acompanhamento dos processos e pedidos de licença e alvarás para funcionamento anual, enviados à Chefatura Central de Polícia por muitos clubes, permitiunos perceber nos anos seguintes a grande quantidade de pedidos de licença para a polícia de clubes que tinham sua sede no bairro da Gávea. Ficava clara, assim, ao longo daquele período, a força que o associativismo recreativo assumiria na região.

Para entender tal fenômeno, é preciso, antes de mais nada, atentar para as especificidades do bairro da Gávea. Seu crescimento naqueles anos se deu a reboque da consolidação da indústria têxtil no Brasil. Beneficiada com a abundância de algodão e preços baixos, esse ramo de produção estava em plena expansão. A partir do final do século XIX, a indústria têxtil brasileira começou a prosperar, voltando-se principalmente para a exportação. Novas fábricas eram criadas em grande quantidade. Os critérios de localização dessas indústrias obedeciam a alguns requisitos: proximidade com o mercado consumidor, fontes de matéria-prima e setor financeiro. O Rio de Janeiro - que, por ser Distrito Federal, contava com uma infraestrutura privilegiada - correspondia bem àqueles critérios, acabando, assim, por atrair investimentos das indústrias. ${ }^{17}$

A partir de 1870, a expansão das linhas de bonde mudaria as características de algumas regiões, que deixavam seu aspecto rural para converter-se em zonas suburbanas. Exatamente nesse ano foi construída a linha de bonde que ligava o centro da cidade à Freguesia da Gávea. Tal fato acabou por atrair, para uma região antes ocupada por chácaras e sítios, outros tipos de investimento, como a instalação de estabelecimentos fabris. No bojo desse processo, em 1884, era inaugurada ali a fábrica de tecelagem Carioca, investimento da Companhia de Fiação e Tecelagem Carioca. Durante a primeira década do século XX, a empresa foi uma das principais fábricas de tecelagem do Distrito Federal, contando em maior parte com o capital inglês. Em 1889, próximo à Fábrica Carioca, era inaugurada no Jardim Botânico a Fábrica de Tecidos Corcovado, pela Companhia de Fiação e Tecidos Corcovado $^{18}$. A antiga zona rural, ainda pouco povoada, assumia, desse modo, a partir do final do século XIX, uma clara marca fabril.

Ao processo de industrialização se ligava o adensamento populacional do bairro. Ainda no final do século XIX, a Companhia de Fiação e Tecelagem Carioca empreendeu a

\footnotetext{
15 "Carnaval". Jornal do Brasil. 22 fev. 1898.

${ }^{16}$ Ainda que o Chuveiro de Ouro fosse o suposto primeiro clube destinado a festejar exclusivamente o carnaval no bairro da Gávea, o Clube Dramático da Gávea, criado em 1886, também promovia festejos durante os dias de Momo, como neste ano, que realizaram "esplêndida sorrie a fantasia". "Palcos e salões". Jornal do Brasil. 3 fev. 1898 - o que mostra que os costumes dançantes não eram restritos aos espaços carnavalescos.

${ }^{17}$ FAUSTO, Boris. Trabalho Urbano e Conflito Social (1890-1920). São Paulo; Rio de Janeiro: Difel, 1976.

${ }^{18}$ WERD, Elizabeth Von; BASTOS, Ana Rodrigues. O Fio da Meada: estratégia de expansão de uma indústria têxtil. Rio de Janeiro: Fundação Casa de Rui Barbosa; Confederação Nacional da Indústria, 1986, p. 102-103.
} 
construção da Vila Operária, local de moradia dos empregados da fábrica. A Companhia de Saneamento do Rio de Janeiro, por sua vez, terminava no começo do século XX a Vila Sauer, destinada aos mesmos fins, ${ }^{19}$ criando, assim, condições para a habitação da região.

A partir de então, a Freguesia da Gávea passaria a ser ocupada pelos trabalhadores das fábricas, em sua maior parte operários de baixa renda. Tornava-se, com isso, uma região tipicamente operária, na qual se reuniam trabalhadores de origens diversas. Colocados em uma região nova, eles precisavam criar, nas proximidades de seus ambientes de trabalho e moradia, espaços de sociabilidade capazes de articular a nova comunidade. Foi em meio a tal processo que os clubes recreativos viriam a se constituir em uma de suas principais opções de lazer, alimentando o movimento associativo na região.

A partir da fundação do Clube Carnavalesco Chuveiro de Ouro, supostamente o primeiro do bairro, o movimento associativo ligado ao lazer foi crescente na região. Durante toda a primeira década do século XX, principalmente nos seus cinco anos iniciais, houve a criação de vários outros clubes - como o Flor dos Amantes da Gávea, o Flor das Morenas, o Vulcanos da Gávea, o Estrela da Gávea, o Clube Dançante Diamantinos da Gávea, a Sociedade Recreativa do Pessoal do Corcovado, o Clube Musical Recreativo Carioca e o Grupo Carnavalesco Flôr da Gávea. ${ }^{20}$ A grande quantidade de novos clubes sugere a relevância que tais práticas passavam a assumir no cotidiano dos operários do bairro.

O fenômeno dançante não era, evidentemente, restrito ao bairro da Gávea. Por toda a cidade formavam-se, naqueles anos, clubes, sociedades e grupos com finalidade semelhante - constituindo uma "febre dançante" mais ampla que fez desses clubes um dos principais centros recreativos de pessoas pobres do Rio de Janeiro, em sua maioria trabalhadores. Interessa-nos, porém, identificar as particularidades dos clubes dançantes da Gávea, quais os critérios de associação que são possíveis de observar, acompanhando o seu cotidiano por meio do controle sobre eles exercido pela polícia do Distrito Federal - cujos resultados se encontram guardados no Arquivo Nacional, em meio aos documentos da Repartição Central de Polícia do Distrito Federal. Cabia à polícia acompanhar as atividades dos clubes, com fins de controlar tais manifestações. Para obterem o direito de se associar, os membros desses clubes eram obrigados a pedir uma licença anual, além de se submeter a um processo de investigação feita pelo chefe de polícia. Junto ao pedido de licença, os clubes deveriam enviar um estatuto para obter a licença de funcionamento, mostrando como pretendiam se organizar.

No segundo capítulo do estatuto enviado à polícia em 1906, a "Sociedade Carnavalesca Recreativa Flôr da Gávea, com sede à rua Marques de S. Vicente n. ${ }^{88}$ ", que era "composta de operários" 21 , deixava registrado os critérios de admissão de seus sócios: “Art. 20 A sociedade compõe-se de numero ilimitado de associados, podendo a ela

\footnotetext{
${ }^{19}$ Idem, p. 173

${ }^{20}$ Os clubes podem ser encontrados nos pedidos de licença para a Repartição Central de Polícia no Arquivo Nacional, nas seguintes pastas: GIFI 6c- 170 e GIFI 6c- 171.

${ }^{21}$ Arquivo Nacional, GIFI- 6c -365.
} 
pertencer todo o individuo maior de 18 anos de idade, que tenha ocupação honesta, de qualquer nacionalidade, e que a diretoria julgue digno de ser aceito". ${ }^{22}$

De modo muito semelhante, a Sociedade Carnavalesca Flôr dos Amantes da Gávea também especificava, no mesmo ano, que "a sociedade compõe-se de número ilimitado de sócios", "de qualquer nacionalidade e estado desde que a diretoria o julgue digno da Sociedade". ${ }^{23}$ Dessa forma, havia a tentativa de esclarecer que todos os trabalhadores, independente de sua nacionalidade e origem, poderiam integrar aquelas sociedades. Segundo Pereira, tratava-se de um padrão de associativismo bastante difundido, que poderia variar quanto aos critérios de admissão. ${ }^{24}$ Note-se ainda que o valor da mensalidade dessas sociedades era considerado baixo, de apenas $2 \$ 000$ réis, se comparado, por exemplo, ao do Clube dos Travessos que exigia dos sócios $5 \$ 000 .{ }^{25}$ Contribuía, desse modo, para que pessoas de baixa renda pudessem se associar aos clubes, caracterizando sua composição social. Evidenciava-se, portanto, o caráter inclusivo desses grêmios, abertos para a incorporação dos diversos tipos de trabalhadores que compunham a força de trabalho do bairro.

Se os estatutos daquelas sociedades explicitavam que qualquer indivíduo poderia integrar seus quadros sociais, na prática elas expressavam uma identidade bastante restrita, ligada ao próprio bairro. Desse modo, ainda que "todo indivíduo" estivesse apto a compor essas sociedades, não era nenhum acaso que explicitassem na escolha de seus próprios nomes a identificação com o bairro, revelando um eixo de associação e identificação entre esses trabalhadores bastante peculiar, como forma de organizar-se a partir de sua apropriação do espaço.

Ao marcarem a espacialidade em que estavam inseridos, o bairro da Gávea, ambas as sociedades aproximam-se num universo comum de compreensão de sua organização, contudo, faziam questão de marcar o que as diferenciava, caracterizando assim sua experiência de organização. A Sociedade Carnavalesca Flôr dos Amantes da Gávea anunciava, no carnaval de 1906, que sairia com "estandarte e vestimentas luxuosas, com as cores verde, branco e encarnado". ${ }^{26}$ Era o caso também, em 1908, do Flôr da Gávea que,

\footnotetext{
${ }^{22}$ Arquivo Nacional, GIFI- 6c -213.

${ }^{23}$ Arquivo Nacional, GIFI- 6c -171.

${ }^{24}$ PEREIRA, Leonardo Affonso de Miranda. "E o Rio Dançou. Identidade e tensões nos clubes recreativos cariocas (1912-1922)". In: CUNHA, Maria Clementina Pereira (org.). Carnavais e outras f(r)estas: ensaios de história social da cultura. São Paulo: editora da UNICAMP/CECULT, 2002. É interessante notar que o mesmo processo se deu fora dos limites da capital federal, como mostra Uassyr de Siqueira ao estudar os clubes recreativos formados por trabalhadores dos bairros do Bras, Bom Retiro e Bexiga em São Paulo no final do século XIX e primeiros anos do século XX. Cf. SIQUEIRA, Uassyr. "Clubes Recreativos: organização para o lazer". In: CHALOUB, Sidney; AZEVEDO, Elciene; CANO, Jefferson; CUNHA, Maria Clementina Pereira (org.). Trabalhadores na Cidade: cotidiano e cultura no Rio de Janeiro e em São Paulo, séculos XIX e XX. Campinas: editora da UNICAMP, 2009.

${ }^{25}$ Arquivo Nacional, IJ6 563. Maria Clementina Pereira Cunha observa que as pequenas sociedades cobravam de seus sócios em torno de $2 \$ 000$ a $3 \$ 000$ réis, enquanto as sociedades carnavalescas "elegantes" cobravam em média 5\$000, aproximando-se do padrão fixado pelas três Grandes Sociedades. CUNHA, Maria Clementina Pereira. "Mandirobas, pés espalhados e o ameno carnaval dos resedás". In: Ecos da Folia. São Paulo: Cia das Letras, 2001.

26 "Os Peregrinos". Gazeta de Notícias. 27 fev. 1906.
} 
segundo o Jornal do Brasil, além de bailes à fantasia, também festejaria o carnaval externamente, levando às ruas seu pavilhão encarnado, preto e verde. A mesma nota especificava ainda que o clube havia sido criado em 1896, e Francisco Balbino dos Santos havia sido "distinguido com o titulo de 'presidente de momo"” porque "é um dos sócios que tem prestado relevantes serviços à sociedade desde sua fundação". ${ }^{27}$ Dessa forma, homenageavam um sócio que parecia ter relevância para o clube, dando destaque ao seu nome. Tais elementos, como as cores dos estandartes, a data de fundação ou nomes importantes que integravam os clubes convertiam-se em especificidades criadas e afirmadas pelas próprias sociedades para distingui-las, acabando por construir sua identidade singular frente às demais.

Outra distinção com a qual precisavam lidar os diretores desses pequenos clubes era a de gênero. É o que sugere o caso dos Políticos da Gávea, no qual somente homens poderiam se associar - sugerindo, à primeira vista, uma composição masculina para clubes como esses. Dois anos após o pedido de licença dos Políticos da Gávea, no entanto, o Flôr da Gávea realizaria dois "faiscantes bailes" em que o jornal destacava a presença das mulheres em cena: "O grêmio das benfeitoras anexa a mesma, composto de infatigáveis batalhadoras, concorrendo para que os pomposos bailes tenham todos os encantos." ${ }^{28}$ Por intermédio da notícia, percebe-se que o Grêmio das Benfeitoras, pelo menos no carnaval de 1908, teve suas atividades ligadas aos preparativos dos festejos, mostrando a importância que as mulheres do grupo tinham na organização da sociedade. É possível supor que as mulheres que compunham o grêmio tinham um papel significativo na hierarquização interna do clube, por assumirem nele uma função relevante.

Se no caso do Flôr da Gávea não é possível afirmar que as mulheres do grêmio tinham um poder de caráter mais político, exercendo algum cargo administrativo com reconhecimento e visibilidade, o mesmo não se pode dizer do grupo Vulcanos da Gávea (criado em 1906, com sede à rua Dias Ferreira). Em 1906, a Gazeta de Notícias publicava:

São os seguintes os atuais diretores dos Vulcanos da Gávea presidente, Jacinto Jose
da Costa; vice-presidente Guilherme Sant-Martins; 1 secretário, Antonio Cordeiro
das Neves; 2 secretário, Carlos Tanner; tesoureiro, Alfredo Barbosa, 1 procurador,
José Pinto Ferreira; 2 procurador, Americo José da Costa; mestre de canto, Luiz
Jose da Costa; contramestre de canto, João Alves; fiscal, Manuel da Silveira Gomes,
e o incansável Grupo das Amadoras... Vulcanas... constituído das Sras.: Ercilia da
Cunha, presidente; Elvira Guimarães, vice-presidente; Laudelina Barbosa, 1
secretaria; Maria Rosa, 2 secretaria, Luiza da Costa, tesoureira; Bernardina
Cardoso, procuradora; Maria Pinto, 1 fiscal e sócio honorifico Sr. Alfredo Barbosa. ${ }^{29}$

O Jornal do Brasil explicitava ainda que a diretoria do Vulcanos da Gávea era composta por uma dupla administração: cavalheiros e amadoras. ${ }^{30} \mathrm{~A}$ última, composta apenas por mulheres, se mostrava atuante nos dias de carnaval: "Este grupo realizou

\footnotetext{
27 "Bailes". Jornal do Brasil. 22 fev. 1908.

28 "Carnaval". Gazeta de Notícias. 27 fev. 1908.

29 "Carnaval". Gazeta de Notícias. 23 fev. 1906.

30 "Carnaval". Jornal do Brasil. 27 fev. 1906.
} 
sábado, 10 do corrente, em sua sede social, a Rua Dias Ferreira, magnífico sarau de iniciativa, organizada pelas sócias amadoras..." As amadoras assumiam uma função de extrema importância no clube, pois o seu bom funcionamento dependia de uma administração competente. Além disso, essa importância nos dias de carnaval se convertia num poder simbólico na hierarquia interna do clube, devido à projeção que sua imagem tinha na sociedade. Entretanto, não era somente na diretoria que as mulheres protagonizavam o carnaval no clube, pois "grande número de sócias em alas, vestidas à fantasia, davam guarda de honra ao estandarte", revelando, assim, que sua presença era numerosa e destacada durante os festejos carnavalescos daquele ano no Vulcanos da Gávea. Por meio desses exemplos, vemos que a questão de gênero tornava-se de suma importância para os operários e operárias desses clubes.

Se partiam de suas diferenças na articulação de sua sociabilidade, por outro lado, esses pequenos clubes tornavam-se na prática espaços de construção de laços identitários sólidos entre seus sócios. Por mais que nos critérios de admissão dos clubes houvesse o reconhecimento das diferenças entre os próprios trabalhadores, os clubes eram em geral organizados por meio de laços de sociabilidade constituídos no universo do trabalho. Dentre os casos mais significativos destaca-se o Clube Musical Recreativo Carioca, que ao solicitar a licença para o seu funcionamento no ano de 1912 obtinha resposta favorável da Repartição Central de Polícia. O parecer do investigador informava, na ocasião, que "sobre este clube cabe-me informar ser ele composto de operários da fábrica de tecido 'Carioca' sobre os quais nada conta em desabono de suas condutas". ${ }^{31}$ Era em torno da fábrica em que trabalhavam que se articulava, assim, uma identidade entre os sócios desses clubes. ${ }^{32}$

Ainda mais significativo, no entanto, parecia o caso da Sociedade Recreativa Pessoal da Fábrica Corcovado, "composta de operários da fábrica de tecidos Corcovado". ${ }^{33}$ Em 1906, o primeiro secretário dessa sociedade, de nome Honório de Figueiredo, enviou o pedido de licença anual para a Repartição Central de Polícia. ${ }^{34}$ Se é difícil compreender, em tais documentos, como se tecem as redes de solidariedade expressas nos clubes, uma pista nos é dada pelo próprio Honório de Figueiredo - que alguns anos antes, precisamente em 1904, havia sido testemunha na habilitação de casamento do companheiro Dagoberto de Carvalho, natural do Rio de Janeiro, com Maria Emilia Bulhões Freitas. Nesse documento, constavam algumas informações a respeito de Figueiredo: sua idade era naquele período de

\footnotetext{
${ }^{31}$ Arquivo Nacional, GIFI- 6c -367.

32 Tais considerações não são nenhuma novidade na historiografia, mesmo no caso da Gávea. O estudo sobre as sociedades recreativas na zona portuária e Cidade Nova, o subúrbio de Inhaúma e a zona fabril no distrito da Gávea, nas duas primeiras décadas do século XX, realizado por Marco Pestana, aponta para a relação entre o mundo do trabalho e a sociabilidade nas associações recreativas. O autor observa que algumas dessas sociedades formadas pelos trabalhadores fabris na Gávea sofriam a interferência de seus patrões, o que não tornava os operários menos combatentes, como é possível perceber nas diversas greves realizadas no período. Embora este trabalho não tenha por objetivo abordar a relação entre os clubes e a sua participação dos patrões, veremos, numa leitura a contrapelo, que os laços identitários construídos a partir da afirmação de redes de sociabilidade entre os operários da região nos clubes recreativos articularam-se frente aos interesses do patronato, evidenciando, assim, os limites de controle de tais práticas paternalistas.

33 "Festas operárias". Gazeta Operária. 22 fev. 1902.

${ }^{34}$ Arquivo nacional, GIFI- 6c- 171.
} 
22 anos, natural de Portugal, solteiro, do comércio, morador à rua do Jardim Botânico n.o 16. Como testemunhas, havia ainda Raymundo Garcia, primeiro secretário da Fábrica Corcovado e Eduardo Avelino dos Reis Junior. ${ }^{35}$ Ambos também foram testemunhas no casamento de Eduardo de Bulhões Freitas, que guardava algum parentesco não identificado com Maria de Bulhões Freitas. Em 1902, Eduardo de Bulhões Freitas, natural do Rio de Janeiro e operário, casou-se com Candida Marques da Silva, nascida na mesma cidade. Eduardo de Bulhões Freitas era filho legítimo de Eduardo Leite de Freitas, guarda-livros, português, e de Maria Bello Bulhões Freitas, fluminense, enquanto, sua esposa era filha legítima de Candido Marques da Silva e de Emilia Fernandes da Silva, brasileiros. ${ }^{36}$ Outra testemunha do casamento de Eduardo Bulhões Freitas com a D. Cândida Marques da Silva foi Annibal Tonini, que se casou um ano depois, em 1903, com Julia Bulhões Freitas. Annibal Tonini era operário e nascido na capital federal, filho legítimo de Leonardo Tonini, natural da Itália e de D. Ercília Tonini; Júlia Bulhões Freitas, natural da capital federal, era filha de Eduardo Leite de Freitas e Maria Bello Bulhões Freitas, portanto, irmã de Eduardo Bulhões Freitas. ${ }^{37}$ Nota-se a complexa rede de relações que se construiu entre os trabalhadores da Fábrica Corcovado por meio do matrimônio, mas também por intermédio das relações de trabalho nessa mesma fábrica.

As redes de sociabilidade também eram construídas e expandidas por meio do contato institucional entre os diferentes clubes e seus sócios. Era o caso do Clube Recreativo Carioca, que recebeu no dia 11 de outubro de 1902, nos seus salões, a Sociedade Recreativa do Pessoal do Corcovado e o Clube Diamantino da Gávea. ${ }^{38}$ Em 1902, o Diamantinos a Gávea realizou um sarau "que esteve concorrido pela Flôr da Mocidade Alegre da Gávea e Jardim". No mesmo evento, "esteve representada a Sociedade Recreativa do Corcovado pelos companheiros Arthur da Fonseca, Júlio Marins e Honório de Figueiredo". ${ }^{39}$ A integração entre os trabalhadores do bairro da Gávea tinha como uma via privilegiada os divertimentos promovidos pelos clubes recreativos, ainda que essa frequência entre seus componentes também pudesse mostrar a tentativa de buscar reconhecimento e visibilidade entre os moradores do bairro.

Percebemos, dessa forma, que as redes de sociabilidade entre os trabalhadores que participavam dessa "febre dançante" na Gávea eram criadas a partir de critérios próprios de organização de sua experiência - construindo laços identitários entre seus sócios e também entre outros moradores do bairro que não eliminavam de modo algum os possíveis conflitos decorrentes da própria identidade forjada também nesses espaços de lazer. Ao organizaremse, obtinham a oportunidade de construir costumes e valores compartilhados por meio de suas reuniões sociais, em verdadeiras atividades de caráter político. Contudo, forjaram-se caminhos peculiares de fazer política nesses espaços de lazer, que poderiam extravasar os limites de suas sedes sociais.

\footnotetext{
${ }^{35}$ Arquivo nacional, Ano 1904, número 2449, caixa 369, Gal A (Dagoberto de Carvalho).

${ }^{36}$ Arquivo nacional, Ano 1902, número 2942, caixa 394, Gal A (Eduardo Bulhões de Freitas)

${ }^{37}$ Arquivo nacional, Ano 1903, número 1904, caixa 362, Gal A (Anibal Tonini).

38 "Festas operárias". Gazeta Operária. 11 out. 1902.

${ }^{39}$ Idem, 26 out. 1902.
} 


\section{O RITMO E A REZA}

Não eram apenas os eventos festivos que mobilizavam, no período, os trabalhadores da Freguesia da Gávea. Em ocasiões menos lúdicas, como o dia de Finados, as solidariedades expressas no cotidiano do bairro se afirmavam também de modo claro. Em 1902, por exemplo, o Jornal do Brasil noticiava que a frequência aos cemitérios havia sido "enorme" ${ }^{40}$, mostrando a importância de homenagens fúnebres para grande parte da população na capital federal. No caso da Gávea, essa questão mostrava-se particularmente importante para os trabalhadores - como sugere o noticiário da Gazeta Operária. Fundada em 1902, e destinada à propaganda socialista, a folha buscava se aproximar do cotidiano dos operários, inserindo temas de seu interesse. Dessa forma, no dia 26 de outubro de 1902, publicava:

Os incansáveis companheiros da fábrica Carioca, a quem exclusivamente se deu toda a propaganda que se tem feito no Jardim Botânico para que no próximo dia 2 de novembro se realize a romaria ao túmulo do saudoso operário Mariano Corrêa e outros, no cemitério de São João Batista, não têm poupado esforços para que esse ato de justa homenagem prestada aos companheiros mortos tenha a imponência necessária. $^{41}$

A Gazeta Operária convocava os trabalhadores da região que abrigava as fábricas de tecelagem Carioca, Corcovado e S. Felix, mostrando o caráter abrangente que o evento propunha realizar. Notas como essa, ocuparam as páginas do jornal durante parte do mês de setembro e todo o mês de outubro.

A comissão que organizou a romaria contava com alguns nomes bem conhecidos pelos operários que integravam os clubes recreativos. Entre eles, o relator do clube Flor da Gávea Alfredo Silva, além de Honório de Figueiredo, integrante da Sociedade Recreativa Pessoal da Fábrica Corcovado e Alfredo Barbosa, sócio benemérito do clube Flor da Gávea e tesoureiro do Vulcanos da Gávea. ${ }^{42}$ Dos onze integrantes da comissão, podemos ainda identificar figuras como João Advinculo de Carvalho, operário da Fábrica Carioca, e Augusto Sande Ferreira, operário da seção de pano desta fábrica. ${ }^{43} \mathrm{Em}$ uma comissão composta por operários do bairro, ressalta-se, assim, a presença maciça de sócios dos clubes recreativos locais.

Entre os organizadores da romaria, o nome que chama a atenção é o de Luiz Barbosa. Operário da fábrica Carioca ${ }^{44}$, ele aparece vinculado, em diferentes momentos, a vários clubes dançantes da região, como o Flôr da Gávea, o Chuveiro de Ouro, o Flor da

\footnotetext{
40 "Mortos". Jornal do Brasil. 3 nov. 1902.

41 "Romaria Mariano Correia”. Gazeta Operária. 26 out. 1902.

42 "Carnaval”. Jornal do Brasil. 15 jan. 1907; "Festas Operárias". Gazeta Operária. 26 out. 1906; "Carnaval de 1906". Gazeta de Notícias. 23 e 24 fev. 1906, respectivamente. Em 1906, Luiz Barbosa seria até homenageado na letra cantada pelo Flôr da Gávea: "A Gazeta de Noticias/ A nossa saudação/ O senhor Luiz Barbosa/ É homem de opinião;/ Faz cumprir nosso dever/ Com tão amável redação". (Gazeta de Notícias. 24 fev. 1906).

43 "Carnaval”. Jornal do Brasil. 12 fev. 1907; Jornal do Brasil. 8 fev. 1907; "Carnaval de 1906". Gazeta de Notícias. 27 fev. 1906; "Carnaval de 1906". Gazeta de Notícias. 16 fev. 1906, respectivamente.

44 “Festas Operárias”. Gazeta Operária. 28 set. 1902.
} 
Carioca e o Vulcanos da Gávea. ${ }^{45}$ Nota-se, no entanto, o fato de que tal ímpeto associativo se desenvolvia em paralelo a uma atenção cuidadosa em relação aos atos fúnebres. No dia 30 de novembro de 1902, quase um mês após a romaria realizada no dia de finados, a Gazeta Operária noticiava na coluna "Notas fúnebres" que o Sr. Luiz Barbosa havia comparecido ao enterro do afilhado de Fortunato Faria Machado, maquinista da fábrica São Felix - ao qual também compareceram Alfredo Barbosa, Miguel Luiz da Silva e jovem operário Juvenal da Mota ${ }^{46}$, ambos integrantes do clube Flôr da Gávea. Nesse evento, apenas mulheres haviam carregado o caixão da criança, sendo este coberto com a bandeira do grupo carnavalesco Felix da Gávea. ${ }^{47}$ O próprio Fortunato Faria Machado era membro de outro clube formado por trabalhadores da localidade, o Flôr da Gávea, compondo o quadro administrativo e exercendo o cargo de 1. secretário em 1906 , sendo que em 1907 já obtinha o título de secretário de honra da mesma sociedade ${ }^{48}$. Também havia falecido o filho do operário da seção de estamparia da Fábrica Carioca chamado José Canalini, e Luiz Barbosa havia comparecido ao seu enterro, assim como diversos companheiros desta fábrica. ${ }^{49}$ Por intermédio desses casos, vemos a importância que Luiz Barbosa e outros operários do bairro atribuíam aos eventos fúnebres que envolviam seus companheiros de folia.

Não era só nos bailes e enterros, no entanto, que Luiz Barbosa aparecia com destaque. Ele, e o companheiro João Bluck, que também compunha a comissão da romaria, atuavam no movimento operário, mais precisamente no Centro das Classes Operárias. ${ }^{50}$ Criado no mesmo ano em que foi realizada a romaria, o Centro tinha a finalidade de tomar para si a tarefa de mobilizar o proletariado. Sua proposta consistia na afirmação e luta do proletariado em face da República e do patronato, tendo como periódicos de propaganda a própria Gazeta Operária e o jornal $A$ Nação. Sem restringir-se à propaganda socialista, o centro tratava de estimular agremiações de trabalhadores de diversas categorias. ${ }^{51}$ Era assim na dupla condição de companheiro de folia dos trabalhadores falecidos e de militante operário que Luiz Barbosa participava de eventos como a romaria de Finados de 1902, na

\footnotetext{
${ }^{45}$ Gazeta de Notícias, 24 fev. 1906.

${ }^{46}$ É possível identificá-lo como operário por meio de sua habilitação de casamento, que informa ainda que ele havia se casado, em 1904, com Albertina Avelina de Jesus, nascida em 1880 "de cor parda", "filha natural de Valentina parda, [então] escrava de Dona Felicidade Perpétua de Jesus". Arquivo Nacional, Ano 1904, caixa 369, Gal A (Juvenal da Motta). O folião era ainda um dos compositores do Clube Flôr da Gávea, publicando em 1906 as seguintes quadras: "Pelo Aquidaban/ E os irmãos perecidos/ Fazemos preces/ Bem condoídos/ Saudemos,/ Saudemos,/ De coração,/ Os bons obreiros/ Nesta canção!". ${ }^{46}$ O trecho faz referência à explosão ocorrida dia 23 de janeiro, na Baía de Guanabara, do navio chamado Aquidaban, que havia tido grande repercussão na cidade do Rio de Janeiro. Interessante observar que se expressa a solidariedade para com os marinheiros mortos, tratados como companheiros. Ao mesmo tempo, as preces "bem condoídas" a que se refere a canção mostram a forma como essa solidariedade se manifestava. É por meio da religiosidade, em pleno dia de festa, que a solidariedade dos irmãos obreiros é afirmada. (Gazeta de Notícias, 24 fev. 1906)

47 "Notas fúnebres". Gazeta Operária. 30 nov. 1902.

48 "Carnaval". Gazeta de Notícias. 24 fev. 1906 e "Carnaval”. Jornal do Brasil. 15 jan. 1907.

49 "Notas fúnebres". Gazeta Operária. 30 nov. 1902.

50 "Centro das Classes Operárias". Gazeta Operária. 28 set. 1902.

${ }^{51}$ GOMES, Ângela de Castro. "República e Socialismo na virada do século". In: A Invenção do Trabalhismo. Rio de Janeiro: Relume Dumará, 1994.
} 
qual chegou a fazer um discurso diante dos túmulos visitados. ${ }^{52}$ Erika Arantes identificou a existência de diversos foliões militantes entre os trabalhadores da Zona Portuária durante o mesmo período. A autora argumentou que tanto as associações recreativas como as sindicais marcaram a experiência de articulação e organização daqueles sujeitos, construindo sua identidade como trabalhadores. ${ }^{53}$ Nesse sentido, o Sr. Luiz Barbosa é um caso exemplar no bairro da Gávea, articulando as ideologias políticas e as práticas sociais dos operários no bairro. O associativismo recreativo não se deu, portanto, à margem do associativismo sindical. Coloca-se, porém, o problema de compreender alguns dos sentidos possíveis atribuídos àquele evento fúnebre.

Eventos como aquele não deixavam de causar certo desconforto a parcelas do movimento operário mais próximas das doutrinas socialistas e anarquistas. Um dos redatores da Gazeta Operária deixava claro, na ocasião, qual era sua posição sobre a realização do evento:

Embora discordando desse fato pelo caráter religioso que lhe é dado, pois que a nossa visita aos nossos mortos deve ser do dia 1 de maio, todos os anos, contudo os companheiros só demonstram que sabem aureolar aqueles que são seus companheiros em todas as lutas de vida, em todas as alegrias, e que uma vez desaparecidos de entre os vivos, ficam completamente esquecidos. ${ }^{54}$

Seguindo a orientação socialista, que via em manifestações de caráter religioso uma forma de alienação e desagregação do operariado, ${ }^{55}$ o jornalista marcava sua posição contra o evento. Entretanto, tolerava a romaria por ver nela uma forma de consciência entre os companheiros de luta, quando lembrados nesse evento. Para o desconhecido jornalista que escreveu a matéria, a afirmação da identidade dos operários se constituía a partir da lembrança dos companheiros que ficavam esquecidos.

Enquanto isso, para os integrantes da comissão que organizou a romaria, dentre eles, Luiz Barbosa, o sentido de tal manifestação era bastante claro e elaborado do ponto de vista teórico:

Nos, operários, que uma força nos impele: a do Dever e do Direito, nós que desprendemos afoitos os nossos voos pelo mundo nebuloso dos ideais, na romaria de hoje e pela ideia que nos congraça, patenteamos o valor e grandeza das nossas tradições.

[...] Este culto que redemos, suscita duas perguntas: que alcance tem perante a mentalidade moderna e que títulos exige para sacrificar aqueles que recebem as nossas aclamações?

A homenagem a esses pranteados companheiros, tem como todas as iniciativas d'esta natureza, a mesma significação-moral e cientifica.

\footnotetext{
52 “Romaria Mariano Correa”. Gazeta Operária. 9 nov. 1902.

${ }^{53}$ ARANTES, Érika Bastos. O Porto Negro: trabalho, cultura e associativismo dos trabalhadores portuários no Rio de Janeiro na virada do XIX para o XX. Tese (Doutorado). Niterói: UFF, 2010, p. 140.

54 "Romaria Operária". Gazeta Operária. 2 nov. 1902.

${ }^{55}$ SCHMIDT, Benito Bisso. “Os partidos socialistas na nascente República”. In: Formação das tradições (18891945). Rio de Janeiro: Civilização Brasileira, 2007.
} 
Moral, porque é nas tradições altivas do passado que nós operários, bebemos a energia para a luta e a fé que nos garante a vitoria, cientifica porque essa homenagem, traz como que como uma auréola formada pela luz verdade suprema: a lei da evolução.

[...] A romaria que se verifica d'aqui a poucas horas, deve encher de justo desvanecimento e satisfação indizível aos companheiros verdadeiramente inspirados nas ideias e sentimentos deste século.

[...] Porque são o reconhecimento colhido na eloquência dos fatos, que não mente, na lógica da historia que não engana.

Descansai, pois companheiros, que continuaremos na gloriosa causada, da conquista dos nossos diretos. Descansai em paz, que essa Humanidade, diante de nossos exemplos de valor fortalecidos pela Razão, guiada pelo homem moderno, ha de erguer o edifício social ao nível do ideal.

[...] Curvemos a cabeça ante a luz irradiante que nos vem dos túmulos de todos os nossos irmãos de sacrifícios! $!^{56}$

Apesar de longo, o trecho é bastante elucidativo para acompanhar a relação que estabeleciam entre os operários presentes no evento e os ritos funerários ao processo de articulação da classe. O eixo da argumentação dessa justificativa foi baseado, principalmente, em dois aspectos: ciência e moral - que, como observou Schmidt, constituía a base de atuação dos partidários do socialismo no período. Segundo o autor, no contexto do começo do século XX, o socialismo era entendido pelos adeptos da ideia como parte de um processo de evolução, em que a regeneração moral da sociedade cumpriria um papel gradual do desenvolvimento socialista. ${ }^{57}$

A comissão justificava a romaria a partir da ideia de ciência, construindo uma narrativa que se aproximava da argumentação da doutrina socialista, contudo, inovava ao reconhecer as tradições como meio de obter as vitórias dos trabalhadores, revelando uma perspectiva intrigante. O envolvimento com o movimento operário fazia com que os integrantes da comissão vissem no socialismo um projeto para o futuro; entretanto, era por meio da afirmação das tradições que eles enxergavam uma estratégia de luta para o presente. Diferente do jornalista, que via nas manifestações de caráter religioso um efeito nocivo, mas tolerável porque a lembrança aos companheiros mortos despertava a consciência entre os operários, aqueles entendiam que o culto era efetivamente uma forma de afirmar a luta entre os operários - não apenas pela lembrança de seus companheiros, como queria o jornalista da Gazeta Operária, mas principalmente pela prática ritual da homenagem aos mortos. Apropriavam-se das ideias circuladas no meio sindical e partidário socialista de maneira bastante particular, legitimando suas práticas culturais num espaço que se pretendia orientar e organizar os trabalhadores, colocando sua concepção de como deveriam proceder.

Para os organizadores da romaria, a realização do evento baseava-se em costumes compartilhados pelos trabalhadores locais, que constituiriam uma forma de articular os trabalhadores para a luta social. Era por dentro dessa lógica que viam na romaria um meio de propagandear o socialismo e criar a consciência entre os companheiros.

\footnotetext{
56 “Romaria Mariano Correa”. Gazeta Operária. 28 out. 1902.

${ }^{57}$ SCHMIDT, Op. cit., p. 174.
} 
Não parecia despropositada a perspectiva desses líderes operários da Gávea. O redator enviado pela Gazeta Operária para cobrir o evento foi testemunha de seu grande poder de mobilização entre os operários locais: "É indiscutível o que observamos em todas as fisionomias, que consternados contemplavam o túmulo de seus irmãos de sacrifícios." ${ }^{58}$ Se a ele bastava a constatação dessa força, que fazia dos ritos fúnebres simples ocasião de propaganda socialista, havia ali algo que escapava à sua compreensão, que ele não chegou a tentar entender: Por que, afinal, a questão fúnebre era reivindicada como uma tradição operária pela comissão da romaria?

Uma pista para tentarmos responder a tal questão está nos grupos que se fizeram representar na romaria. Compareceram a ela as "comissões do Clube Diamantinos da Gávea, dos grupos Clube Chuveiro de Ouro, Flôr da Gávea e famílias diversas de operários". ${ }^{59}$ Ao marcar presença no evento fúnebre na Gávea, os clubes dançantes organizavam seus sócios em procissão na romaria, merecendo, inclusive, espaço na matéria publicada na Gazeta Operária. O problema, no entanto, consiste em identificar o sentido do ato para os operários que faziam parte de tais associações.

Por mais que se tratasse de sociedades dançantes, o tema da morte não deixa de ser abordado em seus estatutos. Nas "Disposições Gerais", dos estatutos aprovados em 1906, os membros da Sociedade Carnavalesca Recreativa Flôr da Gávea definiam o seguinte:

A diretoria (quando permitir) mandará celebrar uma missa no dia 2 de novembro de cada ano, pelo eterno descanso dos associados falecidos, podendo representar no templo em que tiver lugar e, [...] mandará hastear a bandeira em funeral, bem como no caso de falecimento dos associados. ${ }^{60}$

No mesmo ano, o Clube Carnavalesco Flôr dos Amantes da Gávea havia pedido licença para sua criação, enviando o estatuto ao Chefe de Polícia. O artigo 56. especificava uma atividade de maneira bastante semelhante ao congênere Flôr da Gávea, dizendo que a "diretoria mandará rezar quando puder uma missa no dia 2 de novembro de cada ano" e "mandará hastear a bandeira em funeral bem como no caso de falecimentos de sócios". ${ }^{61}$ Não era apenas o dia de finados, no entanto, que aparecia como interesse desses clubes, pois constava também nos artigos dessas organizações o propósito de hastear a bandeira sempre que um associado viesse a falecer, mostrando a preocupação cotidiana dos operários com esse tipo de celebração. A julgar pelos seus estatutos, o tema da morte e os rituais a ela associados apareciam assim, para os operários que compunham aqueles clubes da Gávea, como uma questão de grande importância.

Note-se que nos clubes dançantes da Gávea tais preocupações com os rituais fúnebres não se expressam somente de forma objetiva, por meio de ações mutualistas como o auxílio para enterros ou a proteção às famílias desamparadas. Era por intermédio de uma lógica propriamente religiosa, explícito no comparecimento a rituais fúnebres e na

\footnotetext{
58 “Romaria Operária”. Gazeta Operária. 9 nov. 1902.

${ }^{59}$ Idem.

${ }^{60}$ Arquivo Nacional, GIFI- 6c- 213.

${ }^{61}$ Arquivo nacional, GIFI-6c 171.
} 
realização de missas, que tal preocupação se configurava de forma mais clara. O simbolismo expresso em tais gestos ritualizados é um indício de que uma dimensão possível de construção de solidariedade constituída por esses operários tinha fundamento nas suas tradições e costumes. Nesse sentido, a suposição de que a atenção para com o tema da morte se relacionava apenas a problemas ligados às condições materiais dos trabalhadores, como sugerem Viscardi e Jesus ${ }^{62}$, não basta para explicar a centralidade do tema para esses trabalhadores da Gávea.

Para compreendermos o lugar destacado que a morte assumia nesses clubes dançantes, cabe, dessa forma, atentar para outra dimensão de sua organização: a ligação com as antigas irmandades religiosas formadas por negros durante a segunda metade do século XIX. As ordens terceiras, que eram subordinadas às ordens religiosas, e as irmandades, organizavam-se mediante alguns critérios, que variavam de acordo com a confraria. Os conflitos étnicos interferiam em muitos casos no seu agrupamento, formando, dessa forma, as irmandades destinadas aos "homens de cor" ${ }^{63}$ Colocava-se, nesses espaços de caráter propriamente religioso, a possibilidade de articular dimensões de religiosidade e musicalidade a partir de certa concepção de vida e morte, que acabava por criar rituais fúnebres e festivos. ${ }^{64} \mathrm{O}$ sentido simbólico dessas manifestações forjava visões de mundo em que as celebrações promovidas pelas irmandades aproximavam ritmo e reza num universo comum de atuação ritual.

O esquema simbólico construído naquelas irmandades, que integrava religiosidade, danças e cantos, orientou a lógica associativa dos operários da Gávea nos clubes dançantes, informando sua organização. Por mais que eles tivessem como objetivo primeiro o lazer e a dança, não deixavam, assim, de dar certa ênfase à religiosidade nesses espaços de lazer. Nesse sentido, associando ritmo e reza, os sócios dos clubes construíam e afirmavam valores e costumes, incorporando nas suas atividades cotidianas essa perspectiva. A prática ritual fúnebre e festiva, prevista no estatuto dos clubes dançantes da Gávea se afirmava, assim, entre os operários como uma possibilidade de expressar suas visões de mundo, forjando costumes compartilhados - fossem os do ritmo ou os da reza.

\section{A GREVE}

Apesar da importância que tais manifestações tinham para os trabalhadores da Gávea, nem tudo era festa na região. O desencadeamento de movimentos grevistas como aqueles que paralisavam os trabalhos na Fábrica Carioca nos primeiros dias de 1917 evidenciavam algumas das tensões e desavenças que marcavam a experiência dos moradores do bairro. Como prova dessas tensões, no dia 6 de janeiro de 1917, o jornal $O$

\footnotetext{
${ }^{62}$ FERREIRA, Jorge; REIS, Daniel Aarão. “Mutualismo, Esquerdas e cidadania”. In: A Formação das Tradições (1889-1945). Rio de Janeiro: Civilização Brasileira, 2007.

${ }^{63}$ SOARES. Mariza. Devotos da Cor. Rio de Janeiro: Civilização Brasileira, 2000.

${ }^{64}$ REIS, João José. A morte é uma Festa. São Paulo: Companhia das letras, 1991.p.60.
} 
Paiz noticiava a grande radicalização da greve que mobilizava "aproximadamente três mil operários" da Fábrica Carioca.

\begin{abstract}
Homens, mulheres e crianças em uma indignação geral, abandonaram o trabalhado, correram para o pátio da fábrica num vozerio assustador. Um outro grupo numeroso, invadindo a sessão de teares, deparou com o mestre Dyxson Myller, de nacionalidade inglesa, a quem agrediu socos e pedradas, vingando-se da antiga e geral antipatia.

Nesse ínterim, em outro grupo, aos gritos de lincha, procuravam castigar o mestre geral Eduardo Rester. $\mathrm{O}$ que foi impedido por [...] mais calmos. ${ }^{65}$
\end{abstract}

Aparentemente sem explicação para o jornalista, destacava o caráter violento da manifestação dos operários. Igualmente dura seria a reação da diretoria da fábrica ao punir alguns operários, tidos como agressores do mestre geral. Embora tenha sido noticiado que havia de cem a cento e cinquenta homens e até mulheres envolvidos no ocorrido ${ }^{66}$, parecia que a diretoria demitia aqueles que julgavam líderes do movimento, desconsiderando assim a própria capacidade de articulação e mobilização do conjunto dos operários. Configura-se, assim, uma virulência do movimento grevista que a própria direção da fábrica parecia não compreender, optando por punir apenas as lideranças mais conhecidas, e não o conjunto de trabalhadores.

O fato, porém, é que o caráter violento da manifestação ligava-se à proibição de que comparecessem ao enterro da filha de um companheiro, despertando entre os operários da fábrica uma sólida rede de solidariedade. O Jornal do Brasil deixava entrever esse aspecto ao noticiar que "houve grande descontentamento por parte dos operários e a fábrica em peso foi solidária com os companheiros prejudicados" ${ }^{67} \mathrm{O}$ jornal operário $A$ Razão também enfatizou esse aspecto, publicando que os operários "prestarem toda sua solidariedade, retirando-se todos do recinto da fábrica" ${ }^{68}$ o problema, portanto, não se refere ao motivo imediato da paralisação, e sim ao modo pelo qual puderam se articular, numa rede de solidariedade tão forte e eficaz.

A Gazeta de Notícias fornece uma pista de investigação sobre a lógica do movimento, ao publicar em uma pequena matéria uma explicação mais direta para a greve que havia sido desencadeada na Fábrica Carioca.

\begin{abstract}
Segunda-feira faleceu o empregado da fábrica, Joaquim Morales, que contava grandes simpatias entre os seus companheiros. Estes quiseram acompanhar-Ihe o enterro, e com a banda de música de uma sociedade mantida pelos operários. Obtida a licença do mestre geral Prestes, foram os colegas de Moralles cumprir o último dever de amizade e, como voltassem tarde do cemitério, não tornaram a fábrica, o que contrariou o mestre geral, que ficou descontente com a falta de pessoal.

Dias depois tendo falecido uma menina, filha de um operário da tinturaria de panos, os empregados pediram permissão para acompanhar o enterro. A licença foi
\end{abstract}

\footnotetext{
65 “Greve na fábrica de tecidos carioca”. O Paiz. 6 jan. 1917.

66 "A greve na Carioca”. A Razão. 9 jan. 1917.

67 "Movimento paredista". Jornal do Brasil. 6 jan. 1917.

68 "A greve na Carioca”. A Razão. 6 jan. 1917.
} 
dada condicionalmente e às 4 horas o mestre geral resolveu revogar a ordem anterior, por ter faltado pessoal e lhe parecer inconveniente dispensar o que estava presente. ${ }^{69}$

O jornal noticiou que alguns dias antes os operários da Fábrica Carioca foram dispensados para comparecer à cerimônia funeral do companheiro Joaquim Morales, tesoureiro do Clube Musical Recreativo Carioca, segundo o diretor da fábrica ${ }^{70}$ - indicando que a própria possibilidade de realização desses rituais fúnebres era uma questão a ser negociada entre a diretoria e os operários, constituindo uma dinâmica bastante conflituosa. Em primeiro lugar, nota-se que os trabalhadores do estabelecimento fabril realizaram um ritual em que a banda musical do clube havia acompanhado a celebração, mostrando como os rituais fúnebres realizados naquele espaço de lazer integravam-se às práticas musicais. Em segundo lugar, para os operários que realizaram o enterro, aquele era um evento que compreendia uma duração ritual incompatível com as exigências do mestre geral, que havia exigido o retorno dos operários após a cerimônia, qual a presença da banda de música poderia ter um papel importante, estendendo as celebrações de morte. Apontavam, desse modo, para a importância daquele associativismo no processo de organização e mobilização dos operários da Fábrica Carioca, que se organizavam para realizar rituais fúnebres específicos.

Desse modo, os operários da fábrica não contrariavam apenas as imposições do mestre geral; ao realizarem seus rituais fúnebres, atingiam diretamente a produção da fábrica e consequentemente seus lucros, como sugeria o diretor do estabelecimento fabril Alfred Oliver. ${ }^{71} \mathrm{O}$ jornal $A$ Razão, também apontava para essa questão, ao noticiar que "a teimosia dos diretores da Carioca, determinou já, além de outros, o prejuízo de 20 mil metros de pano que desde sexta-feira [...] e que estão totalmente perdidos... ". ${ }^{72}$ Se para o diretor da fábrica as celebrações fúnebres de seus operários não se justificavam diante do atraso que se encontrava a produção têxtil, para aqueles trabalhadores não havia motivo que os impedisse de prestar às últimas homenagens à filha de seu companheiro. A dinâmica de conflito de interesses que se estabeleceu mostrava a forma como direcionaram suas manifestações políticas naquele evento, ou seja, a tentativa de imposição do ritmo de trabalho submetido à lógica capitalista gerou a própria articulação da experiência compartilhada entre os operários.

Os clubes dançantes tiveram um papel de grande importância nesse processo de organização e mobilização entre os operários da fábrica. Ao realizarem esses rituais fúnebres, criavam costumes compartilhados entre seus sócios, fazendo com que houvesse a possibilidade de se mobilizar coletivamente. Ao levantaram-se para reivindicar o direito de realizar suas práticas culturais, construíam direcionamentos próprios de enfrentamento social, campo tido como possível de atuação do ponto de vista daqueles sujeitos. Era,

\footnotetext{
69 “A greve na companhia Carioca”. Gazeta de Notícias. 7 jan. 1917.

70 "A greve na companhia Carioca". Gazeta de Notícias. 9 jan. 1917.

71 "A greve na companhia Carioca”. Gazeta de Notícias. 9 jan. 1917.

72 “A greve na Carioca”. A Razão. 11 jan. 1917
} 
portanto, a própria realização daquele ritual que estava no centro da indignação dos operários. As crenças e valores, que se expressavam na questão fúnebre, indicavam como a prática desse costume compartilhado tinha força associativa entre os operários, capaz mesmo de mobilizá-los em solidariedade conjunta.

Desse modo, é possível notar a articulação de laços de solidariedade entre os operários da fábrica quando seus companheiros foram demitidos por reivindicar o direito dos demais de realizarem seus rituais fúnebres, como havia argumentado. Porém, é possível perceber que esse elemento estava presente entre os operários de diferentes formas, revelando estratégias de solidariedade coletiva diversificadas. Os operários acusados de agredir o mestre geral Dixson prestaram depoimento na 21. a delegacia de polícia. ${ }^{73}$ De modo bastante semelhante, os três operários forneciam elementos muito gerais de investigação à polícia, não comprometendo nenhum de seus companheiros, e assim, impossibilitando que algum operário fosse acusado do ocorrido. Dessa forma, a solidariedade entre os operários se expressava em diferentes momentos durante a greve, porém, não de forma homogênea entre eles em todas as situações. Era o caso do depoente Euclydes Rosa:

Não tem queixa nenhuma do mestre Dixson. Não lhe consta que os seus colegas de sessão, com exceção apenas da dos teares, que dizer ser ele indelicado para com os operários. Quanto ao mestre geral Preste, não sabe dar informação boas ou más, por não trabalhar com ele; e somente agora que ouviu más referencias a seu respeito. $^{74}$

Ao completar nove dias em greve, a comissão de operários que representava os demais, acabou por resolver pelo retorno ao trabalho. Essa resolução desencadeou "uma nota interessante" no jornal A Razão:

[...] a alma da mulher brasileira explodiu em vibrante protesto partindo da parte feminina das operárias da fábrica. Dir-se-ia que a mulher operária e as crianças estavam mais interessadas na continuação da greve, do que a população masculina da fábrica. E é por isso que os comícios de ontem tiveram mais interesse que os anteriores e o acordo deve fracassar. ${ }^{75}$

O fato de que mulheres e crianças tenham se levantado em favor da continuação da greve pode ter como um de seus fundamentos as próprias condições de trabalho que, segundo o que os jornais apontavam, eram ainda piores. Porém, essa não era a única questão presente nesse evento, pois a questão de gênero destacada pelo jornal aparecia entre as operárias da Fábrica Carioca de modo bastante peculiar. Em primeiro lugar, nota-se que, conjuntamente, essas mulheres protestaram contra a resolução que determinava o retorno às fábricas, merecendo até o registro do jornal como "uma nota interessante". Em segundo lugar, isso se refletia na atividade política do bairro, em que "os comícios de ontem tiveram mais interesse que os anteriores", sugerindo assim sua participação nesse evento.

\footnotetext{
73 "Movimento paredista". Jornal do Brasil. 12 jan. 1917.

74 Idem.

75 “A greve na Carioca”. A Razão. 9 jan. 1917.
} 
Aquele grupo de mulheres que o jornal se referia, expressava sua solidariedade para com os companheiros demitidos da fábrica, mas também entre elas próprias.

Depois de nove dias paralisados, as previsões do jornal operário A Razão, de que "o acordo deve fracassar" entre os operários e a diretoria da fábrica, porque as mulheres e crianças haviam se levantado, não se confirmaram. No dia seguinte, o próprio jornal notificava que os operários e as operárias retornaram ao trabalho. Para o jornal $A$ Razão, a greve havia sido encerrada prematuramente:

Diremos agora dos operários que não agiram como deveriam ter agido. É necessário que o operário brasileiro se convença da indispensabilidade de arregimentação em associações de resistência por classes filiadas a grandes federações, nos moldes da organização operária do velho mundo. ${ }^{76}$

O articulista do jornal atribuía o fim da greve, entendida como um fracasso, ao fato de que nenhuma associação tida como propriamente de classe houvesse organizado a parede. Nesse fragmento, é possível perceber, então, que tipo de concepção de organização de classe o próprio jornal expressava. Os operários deveriam se organizar "em associações de resistência por classes filiadas a grandes federações", como seus companheiros faziam no "velho mundo". A tentativa de reproduzir a organização operária do "velho mundo", como expressou o jornal no fragmento citado, excluía outras formas de associativismo, como os próprios clubes dançantes que se mostravam especialmente importantes para os próprios operários. Se, para os jornalistas, essa parecia uma questão de menor importância para compreender a emergência da greve, para os próprios operários da fábrica, os clubes dançantes tiveram um papel importante no seu processo de organização e mobilização, quando articulavam seus rituais fúnebres às redes de sociabilidade e solidariedade construídas naqueles espaços de lazer.

O caso dos operários da Carioca mostrava que aquela forma de mobilização se valeu também de outras formas de articulação de solidariedade e identidade - na medida em que foi por meio das redes tecidas nesses outros espaços que os trabalhadores viram a possibilidade e a necessidade de se mobilizar em defesa de seus costumes, articulando coletivamente elementos de sua experiência cotidiana. Por intermédio desse episódio, os operários da Fábrica Carioca mostravam, por dentro de sua cultura, a lógica de articulação de suas redes de identidade e solidariedade de classe. Por meio das celebrações de morte realizadas pelos operários nos clubes dançantes, a dimensão religiosa estava presente como um elemento de formação da identidade e solidariedade entre os trabalhadores na Gávea, mostrando que era partir de sua própria experiência, crenças e valores que se articulavam nos momentos de evidente enfrentamento de classe. Se em julho daquele mesmo ano uma nova onda grevista varreria toda a cidade, passando com força pelo bairro da Gávea, parece claro, desse modo, que sua força se devia não apenas à atuação dos militantes anarquistas, como queria o investigador de polícia, ao argumentar um ano após a greve geral que ela contou com "muitos de nossos operários, estimulados, senão guiados, por anarquistas, em

76 “A greve na Carioca”. A Razão. 14 jan. 1917. 
regra estrangeiros". ${ }^{77}$ Para os que experimentaram a greve de janeiro, já parecia claro que a possibilidade de mobilização entre grande parte dos operários da Gávea podia se assentar também em aspectos peculiares de sua experiência, que serviam de base para a sua atuação conjunta.

Recebido em 13/12/2012

Aceito para publicação em 26/01/2013

${ }^{77}$ Arquivo Nacional, IJ6 658. 